\title{
An empirical investigation on factors influencing customer selection of ADSL services
}

\author{
Naser Azad and K. Darabi*
}

Department of Management, Islamic Azad University, South Tehran Branch, Tehran, Iran

\begin{tabular}{|c|c|}
\hline CHRON I C LE & A B S T RACT \\
\hline $\begin{array}{l}\text { Article history: } \\
\text { Received January 18, } 2013 \\
\text { Received in revised format } \\
3 \text { May } 2013 \\
\text { Accepted } 20 \text { May } 2013 \\
\text { Available online } \\
\text { May 25 2013 } \\
\text { Keywords: } \\
\text { Consumer behavior } \\
\text { Marketing mix } \\
\text { Customer choice } \\
\text { Broadband }\end{array}$ & $\begin{array}{l}\text { In this paper, we present an empirical investigation on various factors affecting ADSL service } \\
\text { selection in city of Tehran, Iran. The proposed model of this paper uses a standard } \\
\text { questionnaire and distributes it among randomly selected customers who have some } \\
\text { experiences on internet based ADSL products. The study implements factor analysis as well as } \\
\text { weighted regression technique to perform the study. There are eight hypotheses associated with } \\
\text { the proposed study of this paper, which indicates the effects of product marketing, place and } \\
\text { time of marketing mix, process-marketing mix, productivity and quality of marketing mix, } \\
\text { people, promotion and education and physical evidence on customer choice. The results of } \\
\text { factor analysis have confirmed the impacts of the first four factors but the effects of the other } \\
\text { factor were not confirmed. In other words, the results of the survey have indicated that product } \\
\text { marketing, place and time of marketing mix, process-marketing mix and productivity and } \\
\text { quality of marketing mix influence customer choice. However, the other four components } \\
\text { including people, promotion, price and physical evidence do not play essential role on customer } \\
\text { choice. }\end{array}$ \\
\hline
\end{tabular}

\section{Introduction}

During the past few years, there have been many studies associated with marketing planning (Schiffman \& Kanuk, 2000). Kim and Hyun (2011), for instance, investigated the relationships among marketing-mix efforts including channel performance, value-oriented price, promotion, and after-sales service, corporate image, three dimensions of brand equity including brand awareness with associations, perceived quality, and brand loyalty, and market performance. The proposed model considered three distinctive perspectives of business markets and after-sales service was also considered as a key marketing-mix effort. Corporate image was considered as a mediator from the marketing-mix efforts to the dimensions of brand equity. In their approach, personal selling was described as a key component of promotion and it was examined within the context of a Korean IT software sector. They reported that all the marketing-mix efforts positively influenced the overall 
value of brand equity, which was a proxy of market performance, via the three dimensions of brand equity. In addition, corporate image mediated the impact of the marketing-mix attempts on the three dimensions of brand equity. Satit et al. (2012) investigated the relationship between the 4Ps (Kotler, 2009; Kotler \& Armstrong, 2009), namely price, promotion, place and product, and customer decision-making over travel agents in Palembang, Indonesia. Travel agents were considered for these 4Ps activities to ensure that they could allocate their resources efficiently. They reported that only product and price were associated with customer decision-making over travel agents. Based on the findings, strategic recommendations were recommended for the travel industry in Indonesia.

Kwon (2011) considered the relationship between marketing mix and customer retention for Tongkat Ali coffee by investigating the link associated with cause and effect relationship between marketing mix and customer retention. He reported that product attributes and promotional activities had a positive relationship with customer retention but price and place did not have any relationship with customer retention. Customer preference, positive customer experience, satisfaction and lasting customer loyalty are factors, which influenced the relationship between marketing mix and customer retention. Chattopadhyay et al. (2012) provided an academic database of literature over the period 2000-2010 and proposed a classification scheme for the articles. The survey analysis provided a roadmap to guide future research and aid knowledge accretion and establishment pertaining to the application of ANN based techniques in market segmentation.

\section{The proposed study}

The proposed study of this paper considers the effects of ten variables on marketing mix as follow,

Hypothesis 1:

$\mathrm{H}_{0}$ : Product marketing mix has no impact on customer choice.

$\mathrm{H}_{1}$ : Product marketing mix has some impact on customer choice.

Hypothesis 2:

$\mathrm{H}_{0}$ : Place and time of marketing mix has no impact on customer choice.

$\mathrm{H}_{1}$ : Place and time of marketing mix some impact on customer choice.

Hypothesis 3:

$\mathrm{H}_{0}$ : Process-marketing mix does not impact on customer choice.

$\mathrm{H}_{1}$ : Process-marketing mix influences on customer choice.

Hypothesis 4:

$\mathrm{H}_{0}$ : Productivity and quality of marketing mix has no impact on customer choice.

$\mathrm{H}_{1}$ : Productivity and quality of marketing mix influences on customer choice.

Hypothesis 5:

$\mathrm{H}_{0}$ : People involved in marketing mix have no impact on customer choice.

$\mathrm{H}_{1}$ : People involved in marketing mix influence on customer choice.

Hypothesis 6:

$\mathrm{H}_{0}$ : Promotion and education marketing mix have no effect of on customer choice.

$\mathrm{H}_{1}$ : Promotion and education marketing mix influence on customer choice.

Hypothesis 7:

$\mathrm{H}_{0}$ : Price marketing mix has no effect on customer choice.

$\mathrm{H}_{1}$ : Price marketing mix influence on customer choice. 
Hypothesis 8:

$\mathrm{H}_{0}$ : Physical evidence marketing mix has no impact on customer choice.

$\mathrm{H}_{1}$ : Physical evidence marketing mix influences on customer choice.

The proposed study of this paper is described as practical and descriptive, the population of this study includes all subscribers of ADSL system in telecommunication company in city of Tehran, Iran who were approximately 260,167 people as of November, 2012. Sampling process is based on cluster sampling and it uses a confirmatory factor analysis. According to experts' recommendations, sample size should not be fewer than 10 times of the number of variables. According to Meyers et al. (2006) the sample size is calculated as follows,

$$
N=Z_{\alpha / 2}^{2} \frac{p \times q}{e^{2}},
$$

where $N$ is the sample size, $p=1-q$ represents the probability, $Z_{\alpha / 2}$ is CDF of normal distribution and finally $\varepsilon$ is the error term. For our study we assume $p=0.5, Z_{\alpha / 2}=1.96$ and $e=0.99$, the number of sample size is calculated as $N=240$. We have distributed 266 questionnaires and managed to collect 250 filled ones. The questionnaire consists of 24 questions in Likert scale. Table 1 presents the summary of the questions of this survey.

\section{Table 1}

The summary of questions

\begin{tabular}{|c|c|c|}
\hline Factor & Variable & Code \\
\hline \multirow{3}{*}{ Product } & Speed of access & $\mathrm{R} 1$ \\
\hline & Availability & $\mathrm{R} 2$ \\
\hline & Value- added services for ADSL & R3 \\
\hline \multirow{3}{*}{ Place and time } & Delivery time & L1 \\
\hline & Indirect delivery & L2 \\
\hline & Given time service provide & L3 \\
\hline \multirow{3}{*}{ Process } & Monthly payment methods & $\mathrm{C} 1$ \\
\hline & Installation modem facilitate & $\mathrm{C} 2$ \\
\hline & online order & $\mathrm{C} 3$ \\
\hline \multirow{4}{*}{ Productivity and quality } & Customer service compared of other operators & D1 \\
\hline & Investigation of complaints & D2 \\
\hline & Stability Service & D3 \\
\hline & Quality of service & D4 \\
\hline \multirow{3}{*}{ People } & Respect to customer & E1 \\
\hline & Skilled and accountable staff & E2 \\
\hline & Staff cheerfully & E3 \\
\hline \multirow{3}{*}{ Promotion and education } & Payment Facilities & M1 \\
\hline & Recommended by previous user & M2 \\
\hline & Brand & M3 \\
\hline \multirow{3}{*}{ Price } & The initial cost of the service & $\mathrm{P} 1$ \\
\hline & Competitors costs compared & $\mathrm{P} 2$ \\
\hline & Non-monetary costs such as time and effort to order & P3 \\
\hline \multirow{2}{*}{ Physical evidence } & Apparent landscape of Sale unit & Y1 \\
\hline & Work clothes staff uniform & Y2 \\
\hline
\end{tabular}

The proposed study of this paper uses factor analysis to find out about the impact of various factors. Cronbach alpha has been calculated as 0.959 and the result of KMO test was equal to 0.855 . These results confirm the overall performance of the questionnaire (Marija et al., 1994. Meyers et al., 2006). 


\section{The results}

In this section, we present details of our survey on testing various hypotheses of this survey based on the implementation of factor analysis.

Table 3

The summary of factor analysis

\begin{tabular}{|c|c|c|c|c|c|c|c|c|c|}
\hline \multirow[b]{2}{*}{ Factor } & \multirow[b]{2}{*}{ Variable } & \multirow{2}{*}{ code } & \multicolumn{7}{|c|}{ Factor } \\
\hline & & & 1 & 2 & 3 & 4 & 5 & 6 & 7 \\
\hline \multirow{4}{*}{$\begin{array}{l}\text { Productivity and } \\
\text { quality }\end{array}$} & Quality of service & D4 & .933 & & & & & & \\
\hline & Stability Service & D3 & .908 & & & & & & \\
\hline & Investigation of complaints & D2 & .829 & & & & & & \\
\hline & $\begin{array}{l}\text { Customer service compared of other } \\
\text { operators }\end{array}$ & D1 & .800 & & & & & & \\
\hline \multirow{2}{*}{ Physical evidence } & Work clothes staff uniform & $\mathrm{Y} 2$ & .360 & & & & & & \\
\hline & Apparent landscape of Sale unit & Y1 & & & & & & & \\
\hline \multirow{3}{*}{ Place and time } & Delivery time & L1 & & .883 & & & & & \\
\hline & Indirect delivery & $\mathrm{L} 2$ & & .872 & & & & & \\
\hline & Given time service provider & L3 & & .802 & & & & & \\
\hline \multirow{3}{*}{ Product } & Value-added services for ADSL & R3 & & & .881 & & & & \\
\hline & Availability & $\mathrm{R} 2$ & & & .843 & & & & \\
\hline & Speed of access & R1 & & .362 & .790 & & & & \\
\hline \multirow{3}{*}{ Process } & Online order & C3 & & .353 & & .879 & & & \\
\hline & Monthly payment methods & $\mathrm{C} 1$ & & .338 & & .773 & & & \\
\hline & Installation modem Facilitate & $\mathrm{C} 2$ & & .463 & & .613 & & & \\
\hline \multirow{3}{*}{ People } & Respect to customer & E1 & .443 & & & & 784 & & \\
\hline & Skilled and accountable staff & E3 & .358 & & & & 784 & & \\
\hline & Staff cheerfully & E2 & .351 & & & & .753 & & \\
\hline \multirow{3}{*}{$\begin{array}{l}\text { Promotion and } \\
\text { education }\end{array}$} & Brand & M3 & & & & & & .788 & \\
\hline & Recommended by previous user & M2 & & & & & & .778 & \\
\hline & Payment Facilities & M1 & & & & & & .707 & \\
\hline \multirow{3}{*}{ Price } & $\begin{array}{l}\text { Non-monetary costs such as time and } \\
\text { effort to order }\end{array}$ & P3 & & & & & & & .806 \\
\hline & The initial cost of the service & P1 & & & & & & & .673 \\
\hline & Competitors costs compared & $\mathrm{P} 2$ & & & .437 & & & & .552 \\
\hline
\end{tabular}

The results of Table 3 indicate that in terms of productivity, quality of service is number one priority followed by stability of services. Physical evidence is another important factor where the uniform of employees is the most important item. In terms of place and time, delivery time is the most important factor followed by indirect delivery. Product is another important factor, where value added services for ADSL is the most important factor. In terms of process, online order is the most important factor. In terms of people, customer believes that he/she must be treated with respect. Promotion and education are others important factors where brand plays essential role followed by word of mouth. Price is the last factor where costs and time play the most important factor. We have also performed standardized regression weights for the factors and the results are summarized in Table 4 as follows,

Table 4

The summary of standardized regression weights

\begin{tabular}{lcc}
\hline \multicolumn{1}{c}{$\mathrm{H}_{0}$} & regression & result \\
\hline Product marketing mix has no impact on customer choice. & 0.803 & rejected \\
\hline Place and time of marketing mix has no impact on customer choice. & 0.799 & rejected \\
Process-marketing mix does not impact on customer choice. & 0.763 & rejected \\
\hline Productivity and quality of marketing mix has no impact on customer choice. & 0.758 & rejected \\
\hline People involved in marketing mix have no impact on customer choice. & 0.134 & confirm \\
Promotion and education marketing mix have no effect of on customer choice. & 0.151 & confirm \\
Price marketing mix has no effect on customer choice. & -0.31 & confirm \\
Physical evidence marketing mix has no impact on customer choice. & 0.131 & confirm \\
\hline
\end{tabular}


Based on the results of Table 4, we can conclude that the first four null hypotheses have been rejected in favor of alternative hypotheses, which means product marketing, place and time of marketing mix, process-marketing mix and productivity and quality of marketing mix influence customer choice. However, the other four components including people, promotion, price and physical evidence do not play essential role on customer choice. Fig. 1 shows details of our findings,

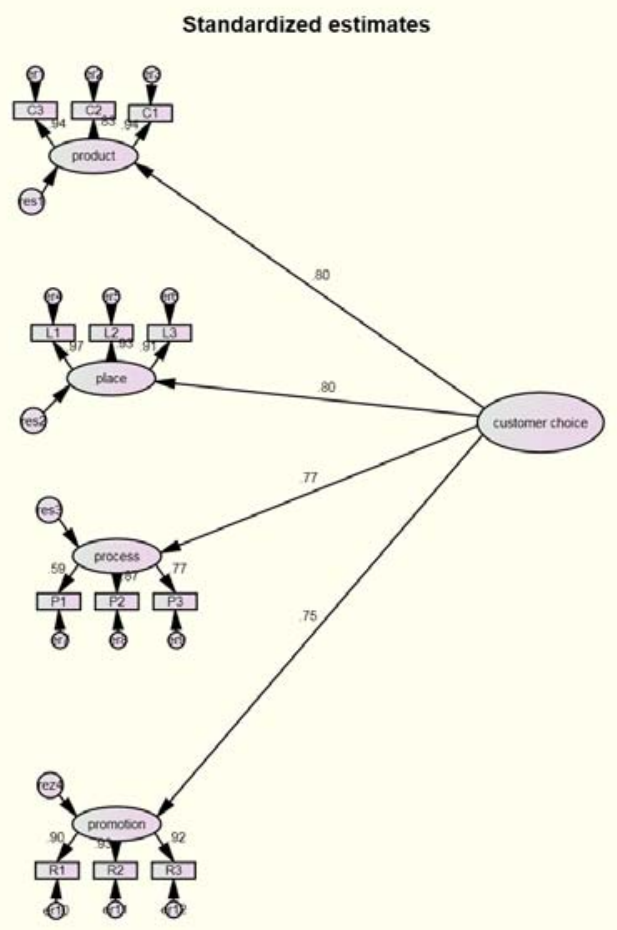

Fig. 1. The summary of regression analysis

\section{Conclusion}

In this paper, we have presented an empirical investigation on different factors influencing ADSL service selection. The proposed model of this paper has designed a questionnaire and distributed among randomly selected customers who use this service in city of Tehran, Iran. The study has implemented factor analysis as well as weighted regression technique to perform the study. The results of the survey have indicated that product marketing, place and time of marketing mix, processmarketing mix and productivity and quality of marketing mix influence customer choice. However, the other four components including people, promotion, price and physical evidence do not play essential role on customer choice.

\section{References}

Chattopadhyay, M., Dan, P., Majumdar, S \& Chakraborty, P. (2002). Application of neural network in market segmentation: A review on recent trends. Management Science Letters, 2(2), 425-438.

Kim, J. H., \& Hyun, Y. J. (2011). A model to investigate the influence of marketing-mix efforts and corporate image on brand equity in the IT software sector. Industrial Marketing Management, 40(3), 424-438.

Kotler, P., \& Armstrong, G. (2009). Principles of marketing. Pearson Education.

Kotler, P. (2009). Marketing management. Pearson Education India. 
Kwon, C. K. (2011). A study of the relationship between marketing mix and customer retention for herbal coffee in Malaysia. In 2nd International Conference on Business and Economic Research (2nd ICBER 2011) Proceeding (No. 2011-279). Conference Master Resources.

Lovelock, C., \& Wright, L. (2002). Principles of Service marketing.

Marija, J., Norušis, \& SPSS Inc. (1994). SPSS professional statistics 6.1. Prentice Hall.

Meyers, L. S., Gamst, G., \& Guarino, A. J. (2006). Applied multivariate research: Design and interpretation. SAGE Publications, Incorporated.

Schiffman, L. G., \& Kanuk, L. L. (2000). Consumer Behavior, 7th.

Satit, R. P., Tat, H. H., Rasli, A., Chin, T. A., \& Sukati, I. (2012). The relationship between marketing mix and customer decision-making over travel agents: An empirical study. International Journal of Academic Research in Business and Social Sciences, 2(6), 522530.

Villarejo-Ramos, A. F., \& Sanchez-Franco, M. J. (2005). The impact of marketing communication and price promotion on brand equity. The Journal of Brand Management, 12(6), 431-444. 